\title{
$\beta$-Catenin activity negatively regulates bacteria-induced inflammation
}

\author{
Yingli Duan ${ }^{1}$, Anne P Liao ${ }^{1}$, Sumalatha Kuppireddi ${ }^{1}$, Zhongde $\mathrm{Ye}^{1}$, Mae J Ciancio ${ }^{2}$ and Jun Sun ${ }^{1}$
}

Wild-type (WT) Salmonella typhimurium causes acute intestinal inflammation by activating the nuclear factor kappa B (NF- $\kappa$ B) pathway. Interestingly, WT Salmonella infection also causes degradation of $\beta$-catenin, a regulator of cellular proliferation. Regulation of $\beta$-catenin and the inhibitor of $\mathrm{NF}-\kappa \mathrm{B}, \mathrm{I} \kappa \mathrm{B} \alpha$, is strikingly similar, involving phosphorylation at identical sites, ubiquitination by the same $\mathrm{E} 3$ ligase, and subsequent proteasomal degradation. However, how $\beta$-catenin directly regulates the NF- $\kappa \mathrm{B}$ pathway during bacteria-induced inflammation in vivo is unknown. Using streptomycinpretreated mice challenged with Salmonella, we demonstrated that WT Salmonella stimulated $\beta$-catenin degradation and decreased the physical association between NF- $\kappa \mathrm{B}$ and $\beta$-catenin. Accordingly, WT Salmonella infection decreased the expression of c-myc, a $\beta$-catenin-regulated target gene, and increased the levels of IL- 6 and TNF- $\alpha$, the NF- $\kappa$ B-regulated target genes. Bacterial infection directly stimulated phosphorylation of $\beta$-catenin, both in vivo and in vitro. Closer examination revealed that glycogen synthase kinase $3 \beta$ (GSK-3 $\beta$ ) kinase activity was increased in response to WT Salmonella, whereas non-virulent Salmonella had no effect. siRNA of GSK-3 $\beta$ was able to stabilize $1 \kappa B \alpha$ in response to WT Salmonella. Pretreatment for $24 \mathrm{~h}$ with LiCl, an inhibitor of GSK-3 $\beta$, reduced WT Salmonella induced IL-8 secretion. Additionally, cells expressing constitutively active $\beta$-catenin showed $\mathrm{l} \kappa \mathrm{B} \alpha$ stabilization and inhibition of NF- $\kappa \mathrm{B}$ activity not only after WT Salmonella infection but also after commensal bacteria (Escherichia coli F18) and TNF- $\alpha$ treatment. This study suggests a new role for $\beta$-catenin as a negative regulator of inflammation.

Laboratory Investigation (2007) 87, 613-624; doi:10.1038/labinvest.3700545; published online 26 March 2007

KEYWORDS: $\beta$-catenin; bacteria; inflammation; NF- $\kappa \mathrm{B} ; \mathrm{GSK}-3 \beta$; $1 \kappa \mathrm{B} \alpha$

Bacteria pathogenicity requires overcoming or altering many very effective host defense mechanisms, ${ }^{1}$ including the activation of nuclear factor kappa B $(\mathrm{NF}-\kappa \mathrm{B}) .^{2-4}$ Bacterial invasion of intestinal epithelial cells (IECs) stimulates NF- $\kappa \mathrm{B}$ and, interestingly, degradation of $\beta$-catenin, ${ }^{5}$ a potent transcriptional factor responsible for cellular proliferation and differentiation. It is notable that regulation of $\beta$-catenin and the inhibitor of NF- $\kappa \mathrm{B}, \mathrm{I} \kappa \mathrm{B} \alpha$, are strikingly similar, involving phosphorylation of the same $\mathrm{N}$-terminal serine sequence sites, ubiquitination by the same E3 ligase complex, and subsequent proteasomal degradation. ${ }^{6,7}$ To date, no publications have reported on the physiological significance of $\beta$-catenin's potential inter-relationship with the NF- $\kappa \mathrm{B}$ inflammatory pathway after bacterial infection in vivo.

In this study, therefore, we investigated the role of $\beta$-catenin in modulating the proinflammatory response mediated by NF- $\kappa \mathrm{B}$ subsequent to Salmonella infection in vivo. We examined the possibility that $\beta$-catenin functions as a nega- tive regulator of NF- $\kappa \mathrm{B}$, much in the same way as $\mathrm{I} \kappa \mathrm{B} \alpha$, through physical interaction with NF- $\kappa$ B. Additionally, we established the role of glycogen synthase kinase $3 \beta$ (GSK-3 $\beta$ ), as the negative regulator of $\beta$-catenin's stability and subsequent reactivity with NF- $\kappa \mathrm{B}$ in both in vitro and in vivo Salmonella-induced gastroenteritis models. The results of this study suggest a novel role for $\beta$-catenin as a negative regulator of NF- $\kappa$ B activity in vivo. Stabilizing of $\beta$-catenin has a significant anti-inflammatory effect by reducing NF- $\kappa \mathrm{B}$ mediated proinflammatory activity, thus controlling intestinal inflammation.

\section{MATERIALS AND METHODS}

\section{Bacterial Strains and Growth Conditions}

Bacterial strains included wild-type (WT) Salmonella typhimurium ATCC 14028s, S. typhimurium mutant $\mathrm{PhoP}^{\mathrm{c}}$ and Escherichia coli F18. Bacterial growth conditions were as follows: non-agitated microaerophilic bacterial cultures were

${ }^{1}$ Department of Pathology, The University of Chicago, Chicago, IL, USA and ${ }^{2}$ Department of Medicine, The Inflammatory Bowel Disease Research Center, The University of Chicago, Chicago, IL, USA

Correspondence: Dr J Sun, PhD, Department of Pathology, The University of Chicago, 5841 S Maryland Avenue, Chicago, IL 60637, USA.

E-mail: jsun@bsd.uchicago.edu

Received 07 September 2006; revised 24 January 2007; accepted 25 January 2007 
prepared by inoculation of $10 \mathrm{ml}$ of Luria-Bertani broth with $0.01 \mathrm{ml}$ of a stationary phase culture, followed by overnight incubation $(\sim 18 \mathrm{~h})$ at $37^{\circ} \mathrm{C}$, as described previously. ${ }^{5}$

\section{Cell Culture}

HCT116 CTNNB1 ${ }^{\mathrm{WT} / \Delta 45}$ and its $\beta$-catenin knockout derivative lines, HCT116 CTNNB1 $1^{-/ \Delta 45}$ and $C T N N B 1^{\mathrm{WT} /-}$, were cultured in McCoy's 5A medium supplemented with $10 \%$ ( $\mathrm{vol} / \mathrm{vol}$ ) fetal bovine serum (FBS). MDCK II cells were grown on permeable supports $(0.4 \mu \mathrm{m}$ pore size) in DMEM supplemented with $10 \%$ FBS. The rat small intestinal IEC-18 cell line was grown in DMEM (high glucose, $4.5 \mathrm{~g} / \mathrm{l}$ ) containing $5 \%$ (vol/vol) FBS, $0.1 \mathrm{U} / \mathrm{ml}$ insulin, $50 \mu \mathrm{g} / \mathrm{ml}$ streptomycin, and $50 \mathrm{U} / \mathrm{ml}$ penicillin. The NF- $\kappa$ Bp 65 knockout mouse embryonic fibroblast (MEF p65-/-) and WT MEF p65 $+/+$ were cultured in DMEM supplemented with $10 \%$ FBS.

\section{Streptomycin Pre-Treated Mouse Model}

Animal experiments were performed at the University of Chicago by using specific pathogen-free female C57BL/6 mice (Taconic) that were 6-7 weeks old. Water and food were withdrawn $4 \mathrm{~h}$ before oral gavage with $7.5 \mathrm{mg} /$ mouse of streptomycin ( $75 \mu \mathrm{l}$ of sterile solution or $75 \mu \mathrm{l}$ of sterile water (control)). Afterwards, animals were supplied with water and food ad libitum. Twenty hours after streptomycin treatment, water and food were withdrawn again for $4 \mathrm{~h}$ before the mice were infected with $1 \times 10^{7} \mathrm{CFU}$ of $S$. typhimurium (50- $\mu \mathrm{l}$ suspension in HBSS) or treated with sterile HBSS (control) by oral gavage as described previously. ${ }^{8}$ At 6 and $18 \mathrm{~h}$ after infection, mice were killed, and tissue samples from the intestinal tracts were removed for analysis.

\section{Mouse Colonic Epithelial Cells}

Mouse colonic epithelial cells were collected by scraping from mouse colon including proximal and distal regions. Cells were sonicated in lysis buffer ( $1 \%$ Triton X-100, $150 \mathrm{mM}$ $\mathrm{NaCl}, 10 \mathrm{mM}$ Tris pH 7.4, 1 mM EDTA, 1 mM EGTA, pH 8.0, $0.2 \mathrm{mM}$ sodium ortho-vanadate, protease inhibitor cocktail) and the protein concentration was determined (BioRad). $\beta$ Actin was used as the loading control for all Western blots. Villin, an accepted marker of epithelial cells, ${ }^{9}$ was used as the control for epithelial cell protein content in all Western blots.

\section{Immunoprecipitation}

Immunoprecipitation samples were prepared as described previously. ${ }^{10}$ Blots were probed with anti- $\beta$-catenin antibody (Transduction Laboratories, USA), stripped and reprobed with anti-p50, anti-p65, anti- $\mathrm{I} \kappa \mathrm{B} \alpha$ (Santa Cruz Biotechnology, CA, USA) and anti- $\alpha$-catenin (Zymed, San Diego, CA, USA) antibodies and visualized by enhanced chemiluminescence (ECL). Chemiluminescent signals were collected and scanned from ECL Hyperfilm (Amersham Pharmacia Biotech) with a Scanjet 7400c backlit flatbed scanner (HewlettPackard Co., Palo Alto, CA, USA). For figures, the contrast of images was adjusted, arranged, and labeled in Adobe Photoshop and Adobe Illustrator (Adobe Systems Incorporated, San Jose, CA, USA). Bands were quantified using NIH Image software. The digital images are representative of the original data.

\section{Immunoblotting}

Mouse epithelial cells were lysed in lysis buffer (1\% Triton X-100, $150 \mathrm{mM} \mathrm{NaCl}, 10 \mathrm{mM}$ Tris pH 7.4, $1 \mathrm{mM}$ EDTA, $1 \mathrm{mM}$ EGTA pH 8.0, $0.2 \mathrm{mM}$ sodium ortho-vanadate, protease inhibitor cocktail) and the protein concentration was measured. Cultured cells were rinsed twice in ice-cold HBSS, lysed in protein loading buffer $(50 \mathrm{mM}$ Tris, $\mathrm{pH} 6.8,100 \mathrm{mM}$ dithiothreitol, 2\% SDS, $0.1 \%$ bromophenol blue, $10 \%$ glycerol), and sonicated. Equal amounts of proteins or equal volumes of total cultured cell lysates were separated by SDS-polyacrylamide gel electrophoresis, transferred to nitrocellulose, and immunoblotted with primary antibodies: anti- $\beta$-catenin, anti-p50, anti-p65, anti- $\mathrm{\kappa} \mathrm{B} \alpha$, anti-c-myc (Santa Cruz Biotechnology, CA, USA), anti- $\alpha$-catenin (Zymed, Carlsbad, CA, USA), p-GSK3 $\beta$ (Y216, BD), pGSK3 $\beta$ (Ser9), p- $\beta$-catenin (ser33/37/Thr41 and Thr41/ Ser45, Cell Signal, MA, USA) or $\beta$-actin (Sigma) antibodies and visualized by ECL.

\section{Immunohistochemistry}

Tissues were fixed in $10 \%$ neutral buffered formaldehyde for $2 \mathrm{~h}$, transferred into $70 \%$ ethanol, and processed the next day. Immunohistochemistry for $\beta$-catenin was performed on paraffin-embedded sections $(1 \mu \mathrm{m})$ of mouse colons. Paraffin sections were baked in an oven at $56^{\circ} \mathrm{C}$ for $20 \mathrm{~min}$. The slides were deparaffinized and rehydrated in xylene, followed by graded ethanol washes at room temperature. Antigen retrieval was achieved by boiling of the slides in a microwave oven in $0.01 \mathrm{M}$ sodium citrate buffer $(\mathrm{pH}$ 6.0). Slides were then incubated in hydrogen peroxide $\left(3 \% \mathrm{H}_{2} \mathrm{O}_{2}\right.$ and $1 \%$ FBS in PBS) for $20 \mathrm{~min}$ at room temperature to block endogenous peroxidase activity, followed by incubation for $20 \mathrm{~min}$ in $5 \%$ FBS/PBS to reduce nonspecific background. The samples were incubated with purified mouse anti- $\beta$-catenin antibody (BD Transduction Laboratories, BD Biosciences, San Diego, CA, USA; $1: 50)$ in $1 \%$ FBS/PBS overnight at $4^{\circ} \mathrm{C}$. Samples were then incubated with HRP-conjugated second antibody (Envision $+{ }^{\mathrm{TM}}$ System/HRP Kit, Dako Cytomation, Glostrup, Denmark) for $1 \mathrm{~h}$ at room temperature. Antibody staining was visualized with DAB (Envision $+{ }^{\mathrm{TM}}$ System/HRP Kit, Dako Cytomation), counterstained with hematoxylin, and coverslipped.

\section{Immunofluorescence}

Colonic tissues from the proximal and distal portion of the colon were freshly isolated and embedded in paraffin wax after fixation with $10 \%$ neutral buffered formalin. After preparation of the slides as described above, slides were incubated in $3 \% \mathrm{H}_{2} \mathrm{O}_{2}$ for $20 \mathrm{~min}$ at room temperature to 
block endogenous peroxidase activity, followed by incubation for $20 \mathrm{~min}$ in $5 \%$ BSA with $0.1 \%$ saponin in PBS to reduce nonspecific background. The samples were incubated with rabbit polyclonal NF- $\kappa$ Bp65 (Santa Cruz Biotechnology, $1: 50$ ) and mouse anti- $\beta$-catenin antibodies (BD Transduction Laboratories, BD Biosciences, San Diego, CA, USA; 1:50) for $90 \mathrm{~min}$ at room temperature. Samples were then incubated with goat anti-rabbit Alexa Fluor 488 (Molecular Probes, Invitrogen Detection Technologies, Eugene, OR, USA; 1:200), goat anti-mouse Alexa Fluor 594 (Molecular Probes, CA, USA; 1:200), and DAPI (Molecular Probes 1:10 000) for $1 \mathrm{~h}$ at room temperature. Tissues were mounted with SlowFade (SlowFade ${ }^{\mathbb{R}}$ AntiFade Kit, Molecular Probes) followed by a coverslip, and the edges were sealed to prevent drying. Specimens were examined with a Leica SP2 A OBS Laser Scanning confocal microscope.

\section{siRNA of GSK-3 $\beta$ : Knock-Down Assay}

HuSH 19-21 mer shRNA constructs of GSK-3 $\beta$ are commercially available from OriGene (Rockville, MD, USA). The 21 -nucleotide oligomer against GSK-3 $\beta$ mRNA is AGGACAAGAGATTTAAGAATC. HCT116 cells were seeded in sixwell plates and transfected with $5 \mu \mathrm{g}$ plasmids; the empty vector was used as negative control. After transfection for $48 \mathrm{~h}$, cells were colonized with WT Salmonella for $30 \mathrm{~min}$. Cell lysates were collected for Western blot to detect GSK-3 $\beta$ and $\mathrm{I} \kappa \mathrm{B} \alpha$ protein levels. After transfection for $48 \mathrm{~h}$, cells were colonized with WT Salmonella for $30 \mathrm{~min}$ and incubated in fresh DMEM for $4 \mathrm{~h}$. Total RNA was extracted for real-time PCR to evaluate IL-8 mRNA levels.

\section{Quantitative Real-Time PCR Analysis}

Total RNA was extracted from epithelial cells using TRIzol reagent (Invitrogen, Carlsbad, CA, USA) and reverse transcribed using the iScript cDNA synthesis kit (BioRad, Hercules, CA, USA) according to the manufacturer's directions. The RT cDNA reaction products were subjected to quantitative real-time PCR using the MyiQ single-color real-time PCR detection system (BioRad) and iQ SYBR green supermix (BioRad) according to the manufacturer's directions. IL-8 cDNA was amplified using primers to the human $I L-8$ gene that are complementary to regions in exon $1\left(5^{\prime}\right.$-TGCATAA AGACATACTCCAAACCT) and overlapping the splice site between exons 3 and 4 (5'-AATTCTCAGCCCTCTTCAAA AA). All expression levels were normalized to the GAPDH levels of the same sample, using forward (5'-CTTCACCACC ATGGAGAAGGC) and reverse (5'-GGCATGGACTGTGGTC ATGAG) primers for GAPDH. Percent expression was calculated as the ratio of the normalized value of each sample to that of the corresponding untreated control cells. All realtime PCR reactions were performed in triplicate. All PCR primers were designed using Lasergene software (DNAStar Inc., Madison, WI, USA).

\section{Salmonella-Induced Mouse IL- 6 and TNF- $\alpha$ Secretion}

Mouse blood samples were collected by cardiac puncture and placed in tubes containing EDTA $(10 \mathrm{mg} / \mathrm{ml})$. Mouse IL-6 and TNF- $\alpha$ were measured using the TiterZyme Enzyme Immunometric Assay kits (Assay Designs Inc., Ann Arbor, MI, USA) according to the manufacturer's instructions.

\section{Salmonella-Induced Human IL-8 Secretion}

HT29-C19A or T84 cells plated on inserts were incubated with $\mathrm{LiCl}(30 \mathrm{nM})$ in DMEM for $24 \mathrm{~h}$, followed by Salmonella-containing HBSS $\left(1.6 \times 10^{10}\right.$ bacteria/ml $)$ apically for $30 \mathrm{~min}$, washing $3 \times$ in $\mathrm{HBSS}$, and incubation at $37^{\circ} \mathrm{C}$ for $4 \mathrm{~h}$. Cell supernatants from the basolateral side were removed and assayed for IL-8 by ELISA in 96-well plates (Linbro/ Titertek; ICN Biochemicals, Costa Mesa, CA, USA) as described previously. ${ }^{10}$

\section{Statistical Analysis}

Data are expressed as mean \pm s.d. Differences were analyzed by Student's $t$-test. $P$-values $\leq 0.05$ were considered significance.

\section{RESULTS \\ Direct Physical Interaction between NF- $\kappa$ B/ $\beta$-Catenin in the Mouse Colon}

To investigate physical interaction between NF- $\kappa \mathrm{B}$ and $\beta$-catenin (NF- $\kappa \mathrm{B} / \beta$-catenin) in mucosal inflammation in vivo, we utilized an animal model of bacterial infection after pretreatment with streptomycin. Streptomycin pretreatment reduces the commensal bacteria in the mouse gut and renders the mouse susceptible to Salmonella-induced gastroenteritis. ${ }^{8} \mathrm{PhoP}^{\mathrm{C}}$ is a PhoP-PhoQ constitutive mutation of the WT Salmonella strain $14028 \mathrm{~s}^{11}$ that increases the expression of PhoP-activated genes and represses the synthesis of approximately 20 proteins encoded by the PhoPrepressed genes. Neish et $a l^{4}$ have demonstrated that $\mathrm{PhoP}^{\mathrm{c}}$ is able to prevent $\mathrm{I} \kappa \mathrm{B} \alpha$ degradation and the subsequent activation of NF- $\kappa \mathrm{B}$. Mice were infected with either WT or PhoP Salmonella.

Mice colonized with WT Salmonella for $6 \mathrm{~h}$ showed a relative decrease in $\mathrm{I} \kappa \mathrm{B}$ and $\beta$-catenin in colonic epithelial cells (Figure 1a, WT). The intensity of the Western blot bands showed that total $\beta$-catenin of colon epithelia in WT Salmonella-infected mice was $70 \%$ of that in controls. In contrast, $\mathrm{PhoP}^{\mathrm{c}}$ treatment stabilized $\mathrm{I} \kappa \mathrm{B}$ and increased the amount of total $\beta$-catenin (Figure 1a, PhoP ${ }^{c}$ ). These differences were specific to the epithelial cells, because all values were normalized to villin.

Immunoprecipitation with $\beta$-catenin pulled down both NF- $\kappa$ Bp65 and p50 subunits (Figure 1b). The $\beta$-catenin/ NF- $\kappa \mathrm{B}$ complex was dramatically less in the WT Salmonellainfected mouse (Figure 1b, WT); only about $27 \%$ of that in the control mice. On the contrary, there was more $\beta$-catenin and NF- $\kappa \mathrm{B}$ binding in the $\mathrm{PhoP}^{\mathrm{c}}$-infected mouse, about $121 \%$ of control (Figure $1 \mathrm{~b}, \mathrm{PhoP}^{\mathrm{c}}$ ). 


\section{a}

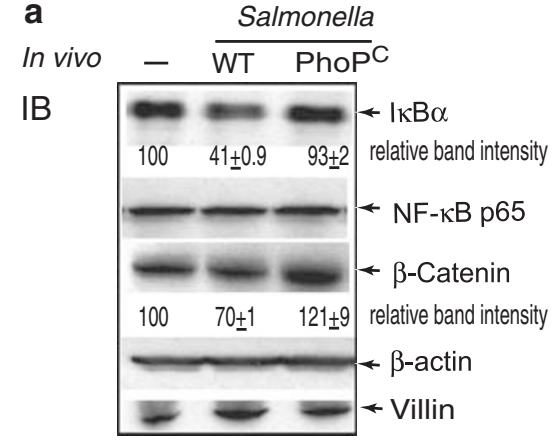

In vivo $-\overline{\text { WT } \text { PhoP }^{C}}$

IB

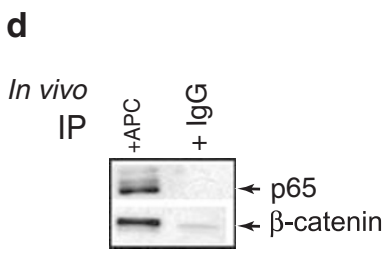

b

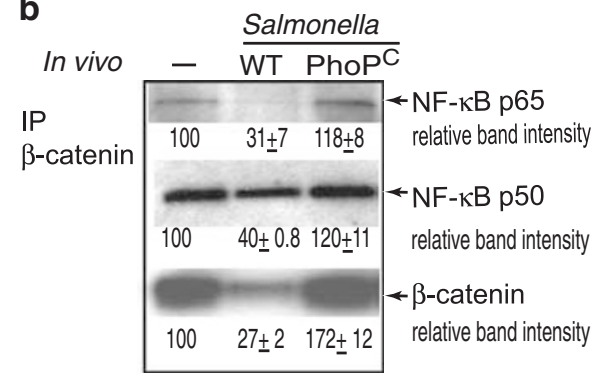

C

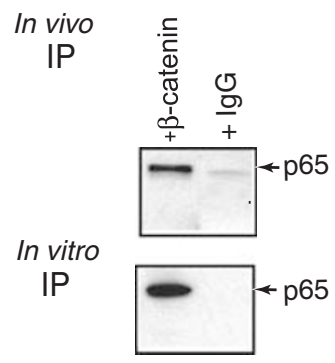

e

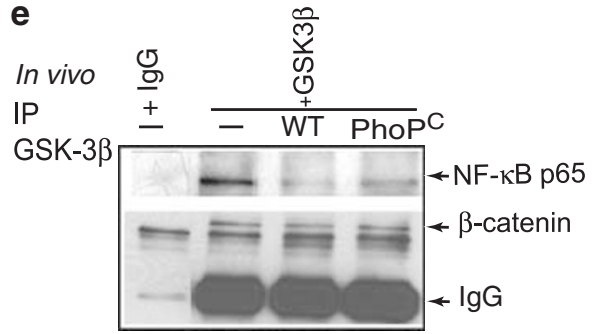

f

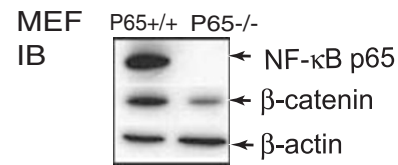

g

\begin{tabular}{|c|c|c|c|c|c|}
\hline No & $\beta$-catenin & APC & GSK-3 $\beta$ & $\mathrm{NF}-\kappa \mathrm{Bp} 50$ & \\
\hline P65-/- & P65-/- & P65-/- & P65-/- & P65-/- & \\
\hline EF P65+/+ & P65+/+ & $\mathrm{P} 65+/+$ & P65+/+ & $\mathrm{P} 65+/+$ & \\
\hline- & $=$ & $\longrightarrow$ & - & $\longrightarrow$ & $\leftarrow N F-\kappa B$ p 65 \\
\hline
\end{tabular}

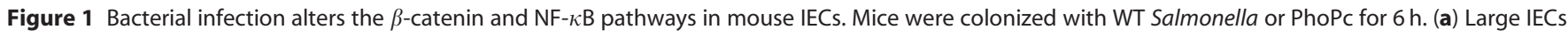
were collected, and cell lysates were analyzed by Western blot for $\mathrm{I} \kappa \mathrm{B} \alpha$, NF- $\kappa \mathrm{Bp} 65$, $\beta$-catenin, villin, and $\beta$-actin. (b) Large IECs were immunoprecipitated with antibodies against $\beta$-catenin, and sequentially Western blotted with antibodies against $\beta$-catenin, NF- $\kappa$ Bp65, and p50. (c) Large IECs (in vivo) and MEF cells (in vitro) were immunoprecipitated with antibodies against $\beta$-catenin and sequentially Western blotted with antibodies against NF- $\kappa$ Bp65. Nonspecific IgG was used as negative control for IP. (d) Large IECs were immunoprecipitated with antibodies against APC and sequentially Western blotted with antibodies against $\beta$-catenin and NF- $\kappa$ Bp65. Nonspecific IgG was used as negative control for IP. (e) Mice were colonized with WT Salmonella or PhoPc for $6 \mathrm{~h}$. Large IECs were immunoprecipitated with antibodies against GSK-3 $\beta$ and sequentially Western blotted with antibodies against $\beta$-catenin and NF- $\kappa$ Bp 65 . (f) $\mathrm{p} 65-/-$ and $\mathrm{p} 65+/+$ MEF cells were collected, and cell lysates were analyzed by Western blot (WB) for NF- $\kappa$ Bp65, $\beta$-catenin, and $\beta$-actin. (g) MEF cells were immunoprecipitated with antibodies against $\beta$-catenin, APC, GSK-3 $\beta$, or p50, and sequentially Western blotted with antibodies against NF- $\kappa$ Bp65. In all instances, the numbers shown represent the relative band intensity compared to control with no treatment (-). Relative band intensities were determined using NIH Image software, and were normalized to control (-) for each sample, which was arbitrarily set to 100. Images shown are representative of 2-3 trials.

In cells not exposed to the stimulation, $\beta$-catenin levels are kept low through interactions with GSK-3 $\beta$, adenomatous polyposis coli (APC), and Axin in the cytoplasm. ${ }^{12-14}$ As positive control, immunoprecipitation with APC was able to pull down $\beta$-catenin (Figure 1d). Immunoprecipitation with IgG was used as a negative control and failed to pull down p65, as shown in Figure 1c and d.

We further assessed whether the $\beta$-catenin/NF- $\kappa \mathrm{B}$ complex was independent of the APC/GSK3 $\beta / \beta$-catenin complex. Immunoprecipitation with APC and GSK-3 $\beta$ was able to pull down $\beta$-catenin and p65 in mouse epithelial cells (Figure 1d and e). Bacterial infection decreased the p65 pulled down by GSK-3 $\beta$, but did not change the amount of GSK-3 $\beta / \beta$-catenin complex (Figure 1e).

Additionally, we tested the $\beta$-catenin/NF- $\kappa \mathrm{B}$ complex in NF- $\kappa$ Bp65 MEF p65-/-. As shown in Figure 1e, p65 was absent in the $\mathrm{p} 65-/-$ MEF. The level of $\beta$-catenin protein was slightly reduced in p65-/- cells (Figure 1f). Co-im- munoprecipitation assays showed that anti- $\beta$-catenin antibody was able to pull down $\mathrm{p} 65$ protein in $\mathrm{p} 65+/+$ MEFs, but not in p65-/- cells (Figure 1g, $\beta$-catenin). Immunoprecipitation of APC or GSK-3 $\beta$ pulled down p65 in WT MEF p $65+/+$, but not in the p65-/- MEF (Figure 1g, APC and GSK- $3 \beta)$. NF- $\kappa$ Bp 50 and p 65 are two subunits of $\mathrm{NF}-\kappa \mathrm{B}$. As positive control, the NF- $\kappa \mathrm{Bp} 50$ subunit was associated with $\mathrm{p} 65$ in $\mathrm{p} 65+/+$. The $\mathrm{p} 65 / \mathrm{p} 50$ association was abolished in p65-/- (Figure 1g). These data confirm the existence of $\beta$-catenin-p65 interaction in mouse fibroblasts. They also suggest that there was binding between NF- $\kappa \mathrm{B}$, GSK-3 $\beta$, and APC.

Taken together, the findings illustrated in Figure 1 indicate a physical interaction between $\beta$-catenin/NF- $\kappa \mathrm{B}$ in normal colonic epithelial cells. WT Salmonella infection decreased the amount of total $\beta$-catenin protein and therefore altered the physical interaction between $\beta$-catenin/NF- $\kappa \mathrm{B}$ in colonic epithelial cells. Additionally, we found no apparent inter- 
action of NF- $\kappa \mathrm{Bp} 50$ with $\alpha$-catenin, a family member of $\beta$-catenin (unpublished data), or with a nonspecific IgG, indicating that the physical interaction between $\beta$-catenin and $\mathrm{NF}-\kappa \mathrm{B}$ determined in vivo is specific.

\section{Localization of $\beta$-Catenin and NF- $\kappa$ B during Inflammation}

The intestinal epithelium lining the gastrointestinal tract has a well-defined architecture. In the normal intestine, there are $\beta$-catenin repression, cell-cycle arrest, and terminal differentiation along the crypt to the villus axis. The crypt-villus junction is also under the control of $\beta$-catenin signaling. In order to investigate the subcellular distribution of $\beta$-catenin and NF- $\kappa \mathrm{Bp} 65$ in the intact colon, tissue sections from mice with or without bacterial colonization were generated and stained with anti- $\beta$-catenin and anti-NF- $\kappa$ Bp 65 antibodies. In the normal colon, without any treatment, NF- $\kappa \mathrm{B}$ was localized in the cytoplasm, and most of the $\beta$-catenin pro- a
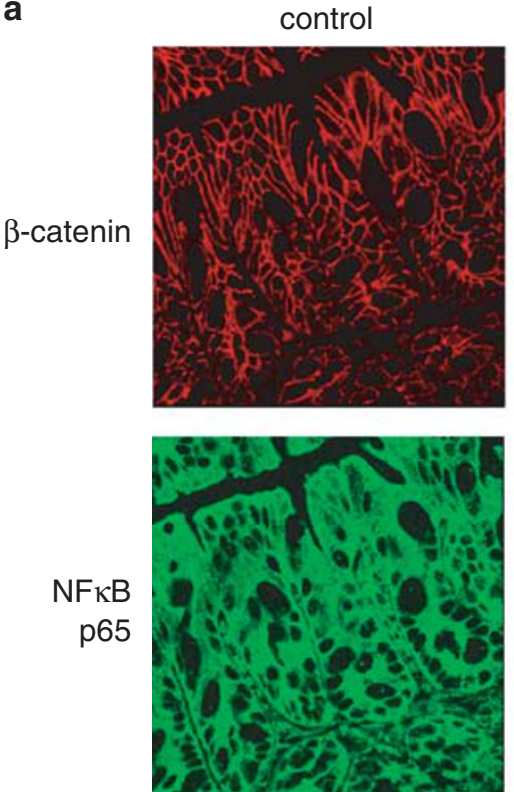

b
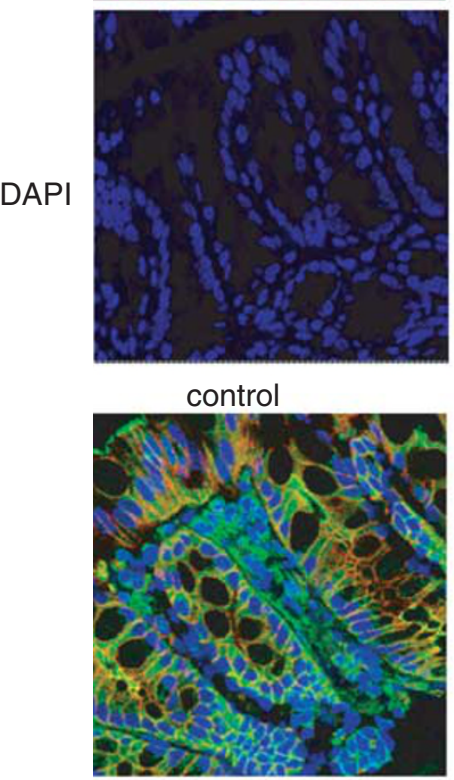

WT Salmonella
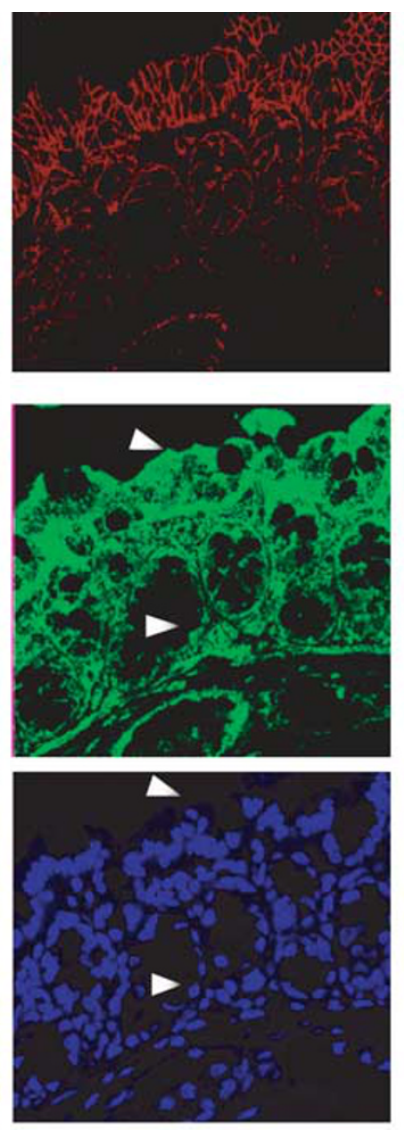

\section{c WT Salmonella}

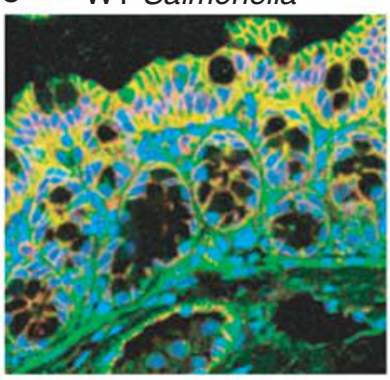

PhoPC
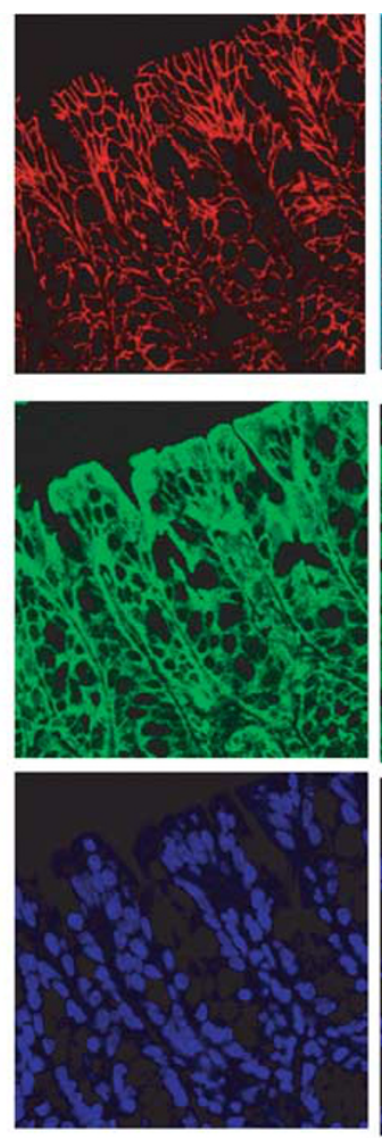

d control

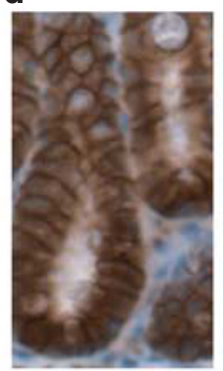

F18
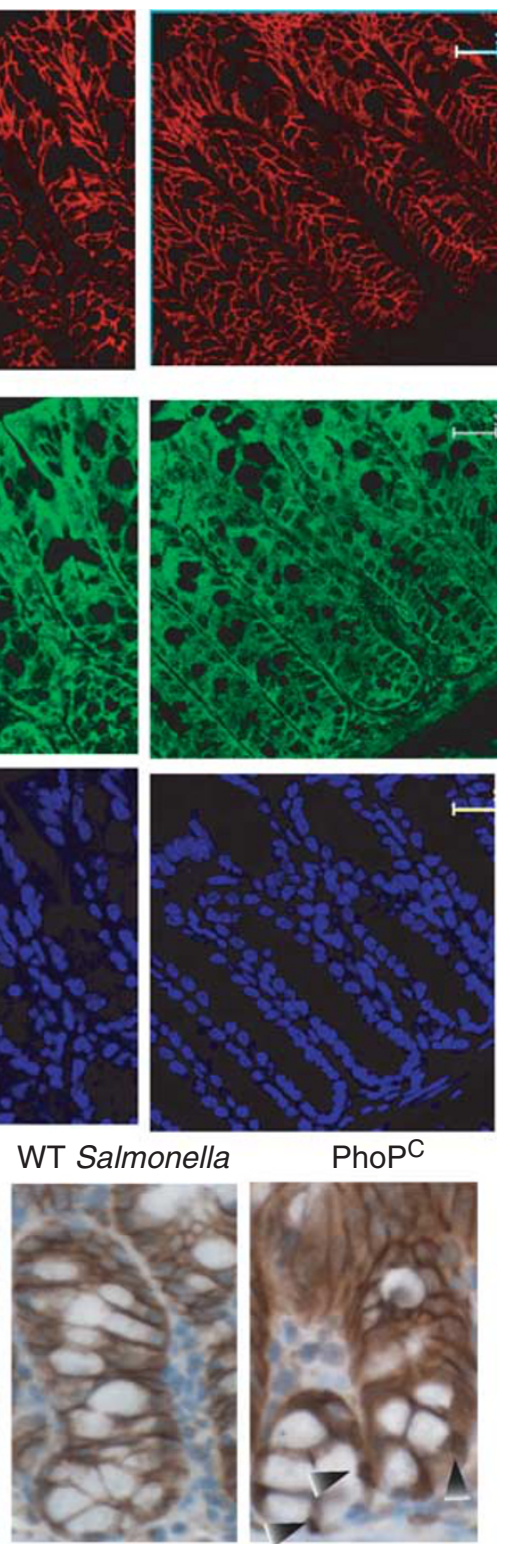

PhoPC

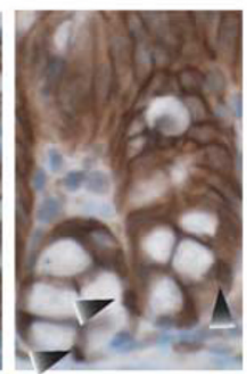

Figure 2 Location of $\beta$-catenin and NF- $\kappa$ B in mouse colon by immunofluorescence. (a) Immunostaining of $\beta$-catenin and NF- $\kappa$ Bp 65 in mouse colon $24 \mathrm{~h}$ after infection with WT Salmonella, PhoP ${ }^{c}$, or E. coli F18. Tissues were fixed, permeabilized, and stained with anti- $\beta$-catenin and anti-p65 antibodies, followed by A488 anti-goat secondary antibodies, A594 anti-mouse FITC-conjugated secondary antibodies, and DAPI. Arrowheads indicate cell nuclei. Images shown are from a single experiment and are representative of three separate repeats. (b) Overlap staining of DAPI, $\beta$-catenin and NF- $\kappa \mathrm{B}$ in normal mouse colon. (c) Overlap staining of DAPI, $\beta$-catenin, and NF- $\kappa$ B in WT-infected mouse colon. (d) $\beta$-Catenin in control, WT Salmonella-, and PhoP ${ }^{c}$-infected mouse colon. Data are representative of at least two independent experiments with similar results. 
teins were located around the cell membrane and in the cytoplasm (Figure 2a, control). There was obvious colocalization of $\beta$-catenin and NF- $\kappa \mathrm{B}$ (Figure $2 \mathrm{~b}$ ), as evidenced by the orange or yellow color, which resulted from a combination of red ( $\beta$-catenin) and green (NF- $\kappa \mathrm{B})$. In contrast, WT bacterial infection for $18 \mathrm{~h}$ induced dramatic changes in the localization and distribution of $\beta$-catenin. Unlike finding in the control tissue, $\beta$-catenin was distributed to the tops of crypts, with very weak $\beta$-catenin staining in the lower parts of the crypts (Figure 2a, WT). We noted that NF$\kappa \mathrm{Bp} 65$ was translocated to the nucleus after WT Salmonella infection, as indicated by white arrowheads (Figure 2a, WT, NF- $\kappa$ Bp65 green, DAPI blue). As shown in the overlap image of Figure 2c, WT Salmonella induced a combination of blue (DAPI) and green (NF- $\kappa \mathrm{B})$. There also was less colocalization of $\beta$-catenin and NF- $\kappa \mathrm{B}$, especially in the lower crypts (Figure 2c), as evidenced by the reduction in yellow color, which results from a combination of red ( $\beta$-catenin) and green $(\mathrm{NF}-\kappa \mathrm{B})$. In tissue sections from mice receiving $\mathrm{PhoP}^{\mathrm{c}}$ or commensal bacteria $E$. coli F18 treatment, $\beta$-catenin was distributed diffusely throughout the membranes (Figure 2a, $\mathrm{PhoP}^{\mathrm{c}}$ and F18), with nuclear staining visible in the lower parts of the crypts (Figure $2 \mathrm{~d}, \mathrm{PhoP}^{\mathrm{c}}$ ), as indicated by black arrowheads. There was no p65 nuclear staining under this condition.

The immunohistochemistry results shown in Figure $2 \mathrm{~d}$ support the fluorescence staining in Figure $2 \mathrm{a}, \mathrm{b}$, and $\mathrm{c}$. In the normal colon, most of the $\beta$-catenin proteins were located around the cell membrane and in the cytoplasm (Figure $2 \mathrm{~d}$, control). The $\beta$-catenin staining in WT Salmonella-treated colons was very light compared to that of the controls and $\mathrm{PhoP}^{\mathrm{c}}$-treated mice in the lower crypts and cell membrane. In $\mathrm{PhoP}^{\mathrm{c}}$-treated mice, the nuclear staining of $\beta$-catenin was visible in the lower part of the crypts (Figure $2 \mathrm{~d}, \mathrm{PhoP}^{\mathrm{c}}$ ), as indicated by black arrowheads.

\section{Bacterial Infection Changes the Expression of Target Genes in $\beta$-Catenin Pathways}

The effect of bacterial colonization on the expression of the $\beta$-catenin transcriptionally regulated target gene, $c-m y c,{ }^{11}$ was investigated in a streptomycin-pretreated mouse model. After infection with either the WT or the avirulent $\mathrm{PhoP}^{\mathrm{c}}$, colonic $c$-myc levels were determined from IEC lysates. As shown in Figure 3a, c-myc expression decreased to about $40 \%$ of the normal control after infection with WT Salmonella for $18 \mathrm{~h}$, but did not decrease when infected with $\mathrm{PhoP}^{\mathrm{c}}$. $C-m y c$ has an essential function in cellular growth and proliferation. ${ }^{15}$ In addition, cyclin D1, a target gene of the $\beta$ catenin pathway, and PCNA, a marker of proliferation, were also decreased by WT Salmonella infection (data not shown).

\section{Bacterial Infection Changes the Secretion of IL- 6 and $T N F-\alpha$, the NF- $\kappa$ B Target Genes}

Colonization of cells with WT Salmonella resulted in the dissociation of NF- $\kappa \mathrm{B}$ from $\mathrm{I} \kappa \mathrm{B} \alpha$ allowing NF- $\kappa \mathrm{B}$ to translocate to the nucleus, where it binds to its recognition sites in the promoter region of a wide variety of genes, including IL-8 (humans) or IL-6 (mouse). IL-6 secretion in mouse plasma (Figure 3b) was observed after WT Salmonella colonization. In vivo colonization with avirulent $\mathrm{PhoP}^{\mathrm{c}}$ and commensal E. coli F18 induced IL-6 secretion $\left(98.3 \mathrm{ng} / \mathrm{ml}\right.$ in $\mathrm{PhoP}^{\mathrm{c}}$ and $71.4 \mathrm{ng} / \mathrm{ml}$ in F18), which was less than $354.5 \mathrm{ng} / \mathrm{ml}$ after WT infection (Figure 3b). Additionally, our real-time PCR data indicated that WT Salmonella colonization induced a 12 -fold increase of IL- 6 at the mRNA level, whereas colonization with avirulent $\mathrm{PhoP}^{\mathrm{c}}$ and commensal E. coli F18 only induced only a onefold increase of IL- 6 mRNA (data not shown). The other cytokine levels, such as that of TNF- $\alpha$ (Figure 3c), were also significantly greater in WT Salmonella-infected mice $(287 \mathrm{ng} / \mathrm{ml})$ than that in $\mathrm{PhoP}^{\mathrm{c}}-(51 \mathrm{ng} / \mathrm{ml})$ or E. coli $\mathrm{F} 18$ $(58 \mathrm{ng} / \mathrm{ml})$ infected mice.
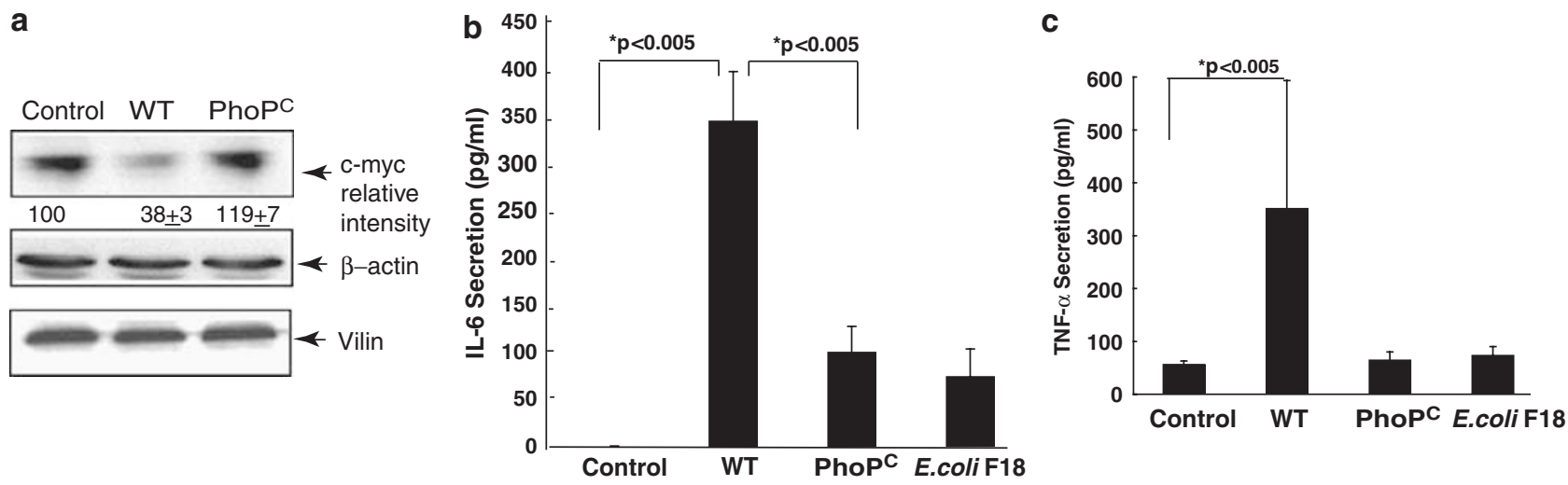

Figure 3 Target gene expression in bacterial-infected mice. (a) Mice were colonized with WT Salmonella or PhoP for $18 \mathrm{~h}$. Mouse colons were collected, and epithelial cells were scraped, lysed, and analyzed for c-myc, villin, and $\beta$-actin levels by immunoblot. Images shown are representative of three trials. $P<0.05$, control compared with WT Salmonella. (b) IL-6 levels in mouse plasma samples $18 \mathrm{~h}$ after WT Salmonella, PhoPc, or E. coli F18 infection. (c) TNF- $\alpha$ levels in mouse plasma samples $18 \mathrm{~h}$ after WT Salmonella, PhoP , or E. coli F18 infection. Data shown in (b) are mean \pm s.d. for $n=3$ experiments. Significance was at $P \leq 0.05$. 
Histological examination of tissues for in vivo WT Salmonella-treated mice supports the cytokine profile, demonstrating tissue inflammation in response to WT Salmonella. In vivo colonization with avirulent $\mathrm{PhoP}^{\mathrm{c}}$ induced less inflammation (data not shown).

\section{Bacteria Modulate $\boldsymbol{\beta}$-Catenin Phosphorylation}

To determine where bacteria are acting to modulate $\beta$-catenin activity, we assessed phospho- $\beta$-catenin ( $\mathrm{p}-\beta$-catenin) levels in mouse colons after infection with WT and $\mathrm{PhoP}^{\mathrm{C}}$ Salmonella. $\beta$-Catenin has been shown to be primed at $S 45$ by CKI (casein kinase I), allowing efficient subsequent serial phosphorylations by GSK-3 $\beta$ on residues T41, S37, and S33. ${ }^{16}$ The phosphorylation of $\beta$-catenin on S33 and S37 is essential for $\beta$-catenin's recognition by the ubiquitin ligase $\beta$-TrCP, which targets it for subsequent degradation. ${ }^{17}$

As demonstrated in Figure 3a, WT Salmonella infection increased $\mathrm{p}-\beta$-catenin, whereas $\mathrm{PhoP}^{\mathrm{c}}$ and F18 decreased $\mathrm{p}-\beta$-catenin in mouse colonic epithelial cells. The increased phosphorylated $\mathrm{I} \kappa \mathrm{B}(\mathrm{p}-\mathrm{I} \kappa \mathrm{B} \alpha)$ is an indicator of the increased NF- $\kappa \mathrm{B}$ activation. We further tested the $\mathrm{p}-\mathrm{I} \kappa \mathrm{B} \alpha$ in mouse colonic epithelial cells. WT Salmonella infection increased $\mathrm{p}-\mathrm{I} \kappa \mathrm{B} \alpha$, whereas $\mathrm{PhoP}^{\mathrm{c}}$ and $\mathrm{F} 18$ decreased $\mathrm{p}-\mathrm{I} \kappa \mathrm{B} \alpha$.

A similar trend for $\mathrm{p}-\beta$-catenin was also found in the cultured epithelial cell models-rat small IEC, IEC-18, Madin-Darby canine kidney (MDCK) epithelial cells, and the human epithelial cell line HCT116 (Figure 4d). Phosphorylation of $\beta$-catenin, expressed as $\mathrm{p}$ - $\beta$-catenin ser33/37/ Thr41, increased in rat small IECs (IEC-18 cells) with WT bacterial colonization (Figure 4b). MDCK cells demonstrated a similar response to WT Salmonella in vitro (Figure 4c), indicating that this response was not specific to rodent cells.

\section{Bacterial Modulation of GSK-3 $\beta$ Phosphorylation}

GSK-3 $\beta$, a critical negative regulator of $\beta$-catenin, also phosphorylates $\mathrm{I} \kappa \mathrm{B}$, the inhibitor of NF- $\kappa \mathrm{B}$ activity. Because of the potential interaction in the NF- $\kappa \mathrm{B}$ and $\beta$-catenin pathways as a result of shared GSK-3 $\beta$ activity, we evaluated the activity of GSK- $3 \beta$ during bacterial infection.

GSK-3 $\beta$ is a constitutively active serine-threonine kinase. Site-dependent phosphorylation of GSK-3 $\beta$ can suppress or enhance its kinase activity. ${ }^{18}$ Specifically phosphorylation of GSK-3 $\beta$ at Ser9 leads to inactivation of its kinase activity. ${ }^{19}$ On the contrary, GSK-3 $\beta$ phosphorylation within the catalytic domain at Tyr216 stimulates GSK-3 $\beta$ kinase activity, resulting in phosphorylation and degradation of $\beta$-catenin. ${ }^{19}$ Phosphorylated GSK-3 $\beta$ levels at Tyr216 and Ser9 are two opposite valid indicators of GSK-3 $\beta$ activity. ${ }^{18}$ Increase of p-Tyr216 and decrease of p-Ser9 indicate the elevated GSK-3 $\beta$ activity, resulting in $\beta$-catenin degradation ( $\uparrow \mathrm{p}$ Tyr216 $=\uparrow$ GSK-3 $\beta$ activity $=\downarrow$ total $\beta$-catenin; $\downarrow$ p-Ser9 $=$ $\uparrow$ GSK-3 $\beta$ activity $=\downarrow$ total $\beta$-catenin). In the streptomycin mouse model, WT Salmonella infection increased phosphorylated GSK-3 $\beta$ (pY216) in colonic epithelia by $50 \%$ within $6 \mathrm{~h}$, whereas $\mathrm{PhoP}^{\mathrm{c}}$ decreased phosphorylated GSK-3 $\beta$

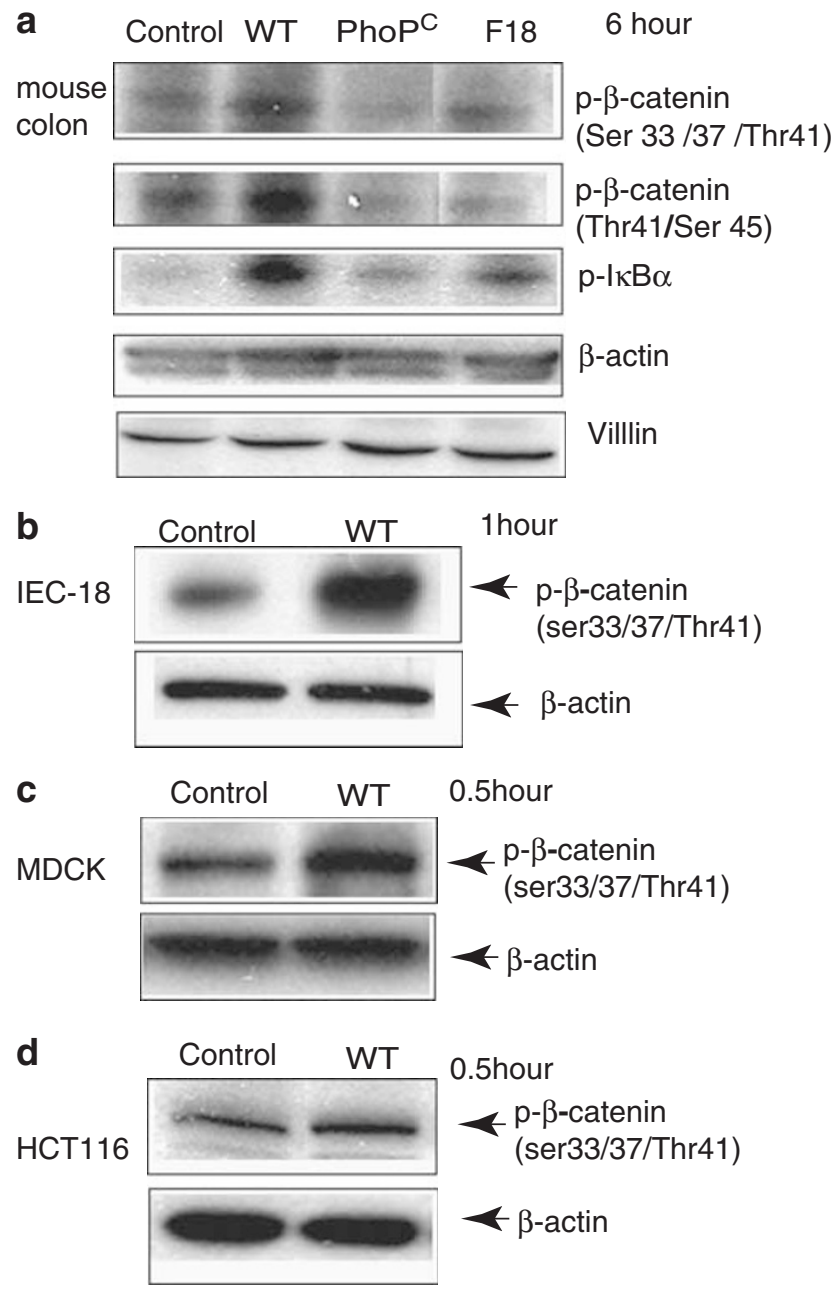

Figure $4 \mathrm{P}$ - $\beta$-catenin induced by bacteria in vivo and in vitro. (a) IECs were harvested from control, WT Salmonella PhoP ${ }^{{ }^{C}}$, and E. coli F18-treated mice $6 \mathrm{~h}$ after treatment. Cells were lysed and analyzed for $\mathrm{p}-\beta$-catenin, $\mathrm{p}-\mathrm{l} \kappa \mathrm{Ba}$, villin, and $\beta$-actin. (b) P- $\beta$-catenin (ser 33/37/Thr41) in IEC-18 cells $1 \mathrm{~h}$ after treatment with WT Salmonella. The images shown are representative of three trials with comparable results. (c) $\mathrm{P}$ - $\beta$-catenin (ser33/37/Thr41) in MDCK cells treated with WT for $0.5 \mathrm{~h}$. (d) P- $\beta$-catenin (ser33/37/Thr41) in HCT116 cells treated with WT for $0.5 \mathrm{~h}$. The images shown are representative of three trials with comparable results.

by $31 \%$, compared to the control without any bacterial infection. In contrast, WT Salmonella infection decreased phosphorylated GSK-3 $\beta$ (Ser9) in colonic epithelia by $48 \%$ within $6 \mathrm{~h}$, whereas $\mathrm{PhoP}^{\mathrm{c}}$ increased phosphorylated GSK-3 $\beta$ (Ser9) by $21 \%$ compared to the control without any bacterial infection (Figure 4a). Bacterial infection did not change the total amount of GSK-3 $\beta$ (Figure $5 \mathrm{a}$ ) or GSK-3 $\alpha$, another member of the GSK-3 family (data not shown). Briefly, our data suggest that bacterial colonization alters GSK-3 $\beta$ activity by stimulating its phosphorylation, which, in turn, influences the $\beta$-catenin-mediated pathways by phosphorylating $\beta$-catenin in colonic epithelial cells.

We also established a GSK-3 $\beta$ siRNA system to knock down the total expression of GSK-3 $\beta$ in HCT116 cells. As 
a

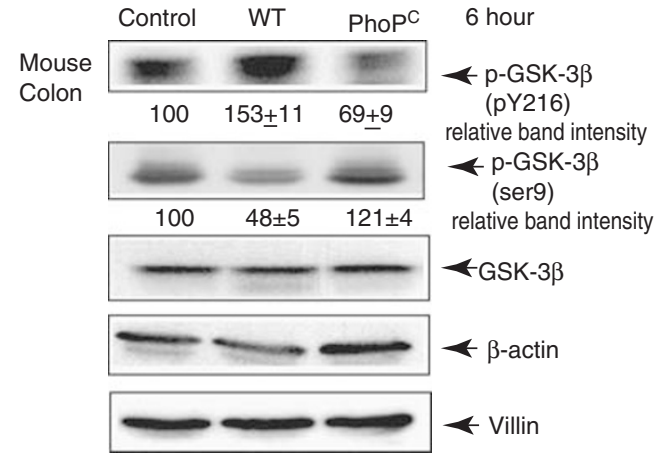

b

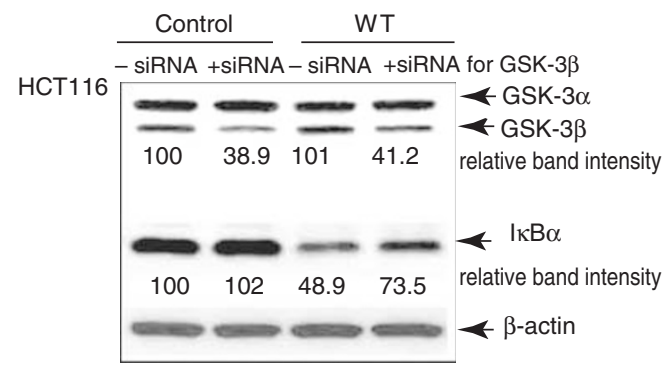

C

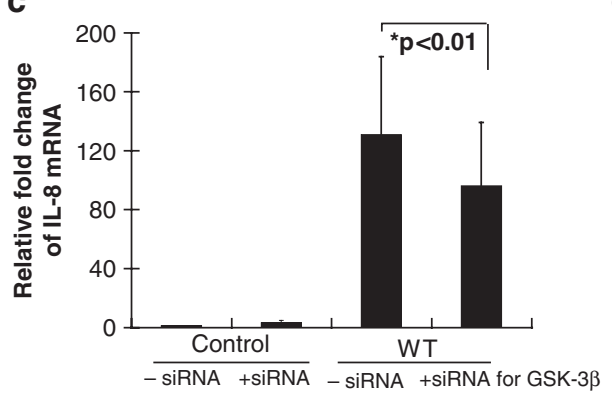

d

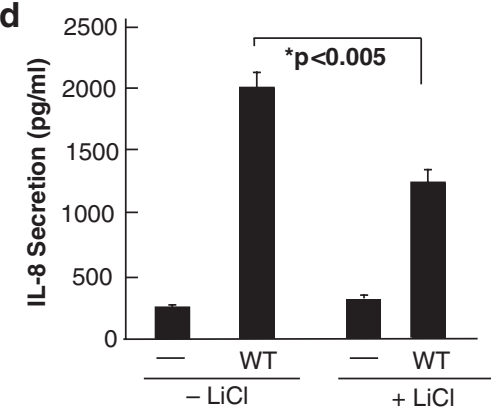

e

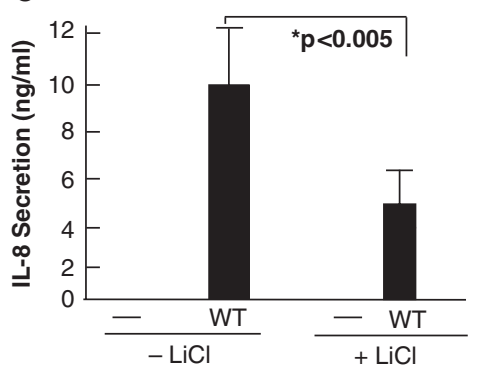

Figure 5 Bacterial infection changed GSK-3 $\beta$ activity. (a) P-GSK-3 $\beta$ activity in mouse colonic epithelial cells $6 \mathrm{~h}$ after WT Salmonella or PhoP ${ }^{\mathrm{C}}$ infection. Bands were quantified using NIH Image software. Data presented are mean \pm s.d. from a single experiment assayed in triplicate, and are representative of results obtained in three separate experiments. (b) GSK-3 $\beta$ siRNA reduced the WT Salmonella-induced $I \kappa B \alpha$ degradation. Bands were quantified using NIH Image software. The GSK-3 $\beta$ siRNA was able to low the total GSK-3 $\beta$ to about $40 \%$ of the control cells. The images shown are representative of two trials with comparable results. (c) GSK-3 $\beta$ siRNA reduced the WT Salmonella-induced IL-8 mRNA. (d) IL-8 secretion in HT29-Cl.19A cell culture supernatants on the basolateral side. (e) IL-8 secretion in T84 cell culture supernatants on the basolateral side. Data presented are mean \pm s.d. from a single experiment assayed in triplicate, and are representative of results obtained in three separate experiments.

shown here, the expression of total GSK-3 $\beta$ and phosphoGSK- $3 \beta$ was decreased by about $43 \%$ (Figure 5 b, + siRNA for GSK3 $\beta$ ), whereas the GSK-3 $\alpha$ expression was not altered. The degradation of the total $\mathrm{I} \kappa \mathrm{B} \alpha$ was less in the siRNAtransfected cells compared to the non-siRNA-transfected cells in response to the WT Salmonella colonization (Figure 5b). Additionally, real-time PCR data showed that the IL-8 mRNA was decreased in the siRNA-transfected cells compared to the non-siRNA-transfected cells in response to the WT Salmonella colonization (Figure 5c).

Further to examine the effects of GSK- $3 \beta$ on Salmonellainduced activation of the NF- $\kappa \mathrm{B}$ pathway, we tested the protective function of $\mathrm{LiCl}$, an inhibitor of GSK-3 $\beta$, in a polarized human colonic epithelial cell line, HT29Cl.19A. Pretreatment for $24 \mathrm{~h}$ with $\mathrm{LiCl}$ reduced IL-8 secretion in response to WT Salmonella (Figure 5d and e). This response was not cell line specific, because polarized human colonic epithelial T84 cells demonstrated the same response as did the HT29Cl.19A cells to WT Salmonella after with $\mathrm{LiCl}$ pretreatment (Figure 5d). Less WT Salmonella-induced IL-8 secretion was detected in the medium of T84 cells after $\mathrm{LiCl}$ pretreatment (Figure 5e). These data are consistent with these in our previous report, which demonstrated that $\mathrm{LiCl}$ pretreatment can inhibit WT Salmonella-induced GRO/CINC-1 (rat IL-8) secretion in a non-transformed rat small intestine cell line. ${ }^{10}$ Taken together, our siRNA and LiCl pretreatment data suggested that inhibition of GSK-3 $\beta$ is able to reduce the $\mathrm{NF}-\kappa \mathrm{B}$ activity in response to the Salmonella colonization.

\section{$\beta$-Catenin Activation Negatively Regulates the NF- $\kappa$ B Pathway during Bacterial Colonization}

To address the possible biochemical and physiological effects of $\beta$-catenin on the NF- $\kappa \mathrm{B}$ pathway, we used a unique cell model: the human epithelial cell line HCT116 with only the mutant $\beta$-catenin allele. ${ }^{20}$ The mutant $\beta$-catenin gene $\Delta 45$ represents a 3 -bp deletion (TCT) that removes codon $45{ }^{21}$ CTNNB1 is the $\beta$-catenin gene. Parental HCT116 cells $\left(C T N N B 1^{\mathrm{WT} / \Delta 45}\right)$ possess the mono-allelic $\beta$-catenin mutation $\triangle 45$ and WT CTNNB1. Chan et al ${ }^{20}$ disrupted the CTNNB1 allele in the parental HCT116 cell line and generated two new cell lines with only one allele: HCT116 $\left(C T N N B 1^{-/ \Delta 45}\right)$ possesses only mutant CTNNB1, and HCT116 (CTNNB1 ${ }^{\text {WT- }}$ ) possesses only WT CTNNB1. These genetically modified cell lines allowed us to test the possible effects of $\beta$-catenin activity on the NF- $\kappa \mathrm{B}$ pathway. In cell line HCT116 $\left(C T N N B 1^{-/ \Delta 45}\right)$ expressing constitutively active $\beta$-catenin, $\mathrm{I} \kappa \mathrm{B} \alpha$ was stabilized; NF- $\kappa \mathrm{B} / \mathrm{DNA}$ binding, and $\mathrm{NF}-\kappa \mathrm{B}$ transcriptional activity were repressed after WT Salmonella colonization. Accordingly, constitutively active $\beta$-catenin was found to inhibit the secretion of IL-8. ${ }^{10}$ 
To test the global effect of $\beta$-catenin activity on inflammatory stimulation, we measured relative $\mathrm{I} \kappa \mathrm{B}$ levels as an indicator of NF- $\kappa \mathrm{B}$ activation after treatment with WT Salmonella, TNF- $\alpha$, and commensal E. coli F18. In $C T N N B 1^{\mathrm{WT} / \Delta 45}$, there was $\mathrm{I} \kappa \mathrm{B}$ degradation after treatment with WT Salmonella, E. coli F18, and TNF- $\alpha$ (Figure 6). These cells responded like normal mouse tissue incubated with

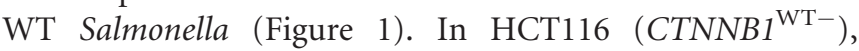
which possesses only WT CTNNB1, the responses to the WT Salmonella, E. coli F18, or TNF- $\alpha$ stimulation were comparable to that in the parental HCT116 cells. However, in $C T N N B 1^{-/ \Delta 45}$, there was less $\mathrm{I} \kappa \mathrm{B}$ degradation induced by
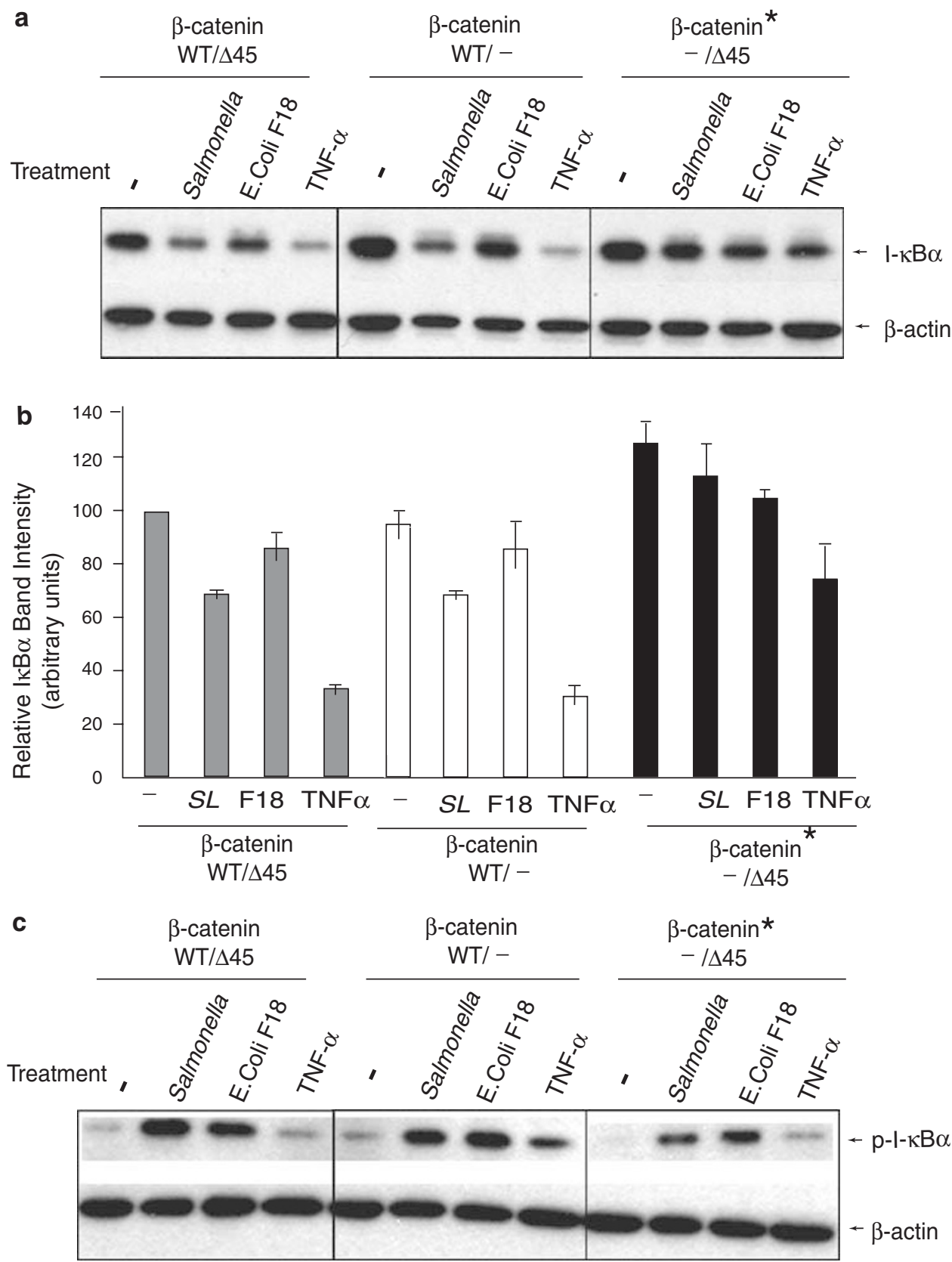

Figure 6 Stabilization of $\beta$-catenin inhibits inflammatory responses. (a) $\mid \kappa \mathrm{B} \alpha$ levels were determined in HCT116 $\beta$-catenin WT/ 445 , HCT116 $\beta$-catenin WT/-, and HCT116 $\beta$-catenin $-/ \Delta 45\left(^{*}\right)$ after treatment with WT Salmonella, E. coli F18, and TNF- $\alpha$ for 30 min. Equal amounts of total cell lysate were sequentially immunoblotted with antibodies against $\mathrm{I} \kappa \mathrm{B} \alpha$ and $\beta$-actin (loading control). Data shown in (a) are representative of four trials. (b) Relative intensity of the Western blot images. Data plotted in (b) are the mean \pm s.d. of $n=4$. SL: Salmonella. (c) $\mathrm{p}-\mathrm{l} \kappa \mathrm{B} \alpha$ levels were determined in HCT116 $\beta$-catenin WT/ $\Delta 45$, HCT116 $\beta$-catenin WT/-, and HCT116 $\beta$-catenin -/L45 after treatment with WT Salmonella, E. coli F18, and TNF- $\alpha$ for 30 min. Equal amounts of total cell lysate were sequentially immunoblotted with antibodies against $\mathrm{p}-\mathrm{l} \kappa \mathrm{B} \alpha$ and $\beta$-actin. These data are from a single experiment that is representative of results obtained in three separate experiments. 
Salmonella, TNF- $\alpha$, and the commensal E. coli compared to the HCT116 parental cells (Figure 6a). The relative intensities of the Western blot bands demonstrated that the baseline of $\mathrm{I} \kappa \mathrm{B}$ is higher in $C T N N B 1^{-/ \Delta 45}$ cells possessing only the $\beta$-catenin mutant $C T N N B 1^{-/ \Delta 45}$ than that in the parental HCT116. Moreover, CTNNB1 $1^{-/ \Delta 45}$ cells showed similar protection of $\mathrm{I} \kappa \mathrm{B} \alpha$ after Salmonella, E. coli F18, or TNF- $\alpha$ stimulation (Figure $6 \mathrm{~b}$ ) relative to the parental cells, and HCT116 (CTNNB1 ${ }^{\text {WT- }}$ ) possessed only WT CTNNB1. Interestingly, the baseline of the $\mathrm{p}-\mathrm{I} \kappa \mathrm{B} \alpha$ was relatively low in CTNNB1 ${ }^{-/ \Delta 45}$ cells. After Salmonella, E. coli F18, or TNF- $\alpha$ stimulation, the $\mathrm{p}-\mathrm{I} \kappa \mathrm{B} \alpha$ was still lower compared to the parental cells and HCT116 (CTNNB1 ${ }^{\mathrm{WT}-}$ ) (Figure 6c). This suggests that the protective effect of constitutively active $\beta$-catenin is not strictly limited to Salmonella-induced $\mathrm{I} \kappa \mathrm{B} \alpha$ degradation.

\section{DISCUSSION}

This study demonstrates a novel role for $\beta$-catenin in IECs as a constitutive negative regulator of inflammation in vivo. By physically binding to NF- $\kappa \mathrm{B}$ and preventing its activation, $\beta$ catenin acts in much the same way as $\mathrm{I} \kappa \mathrm{B} \alpha$ to inhibit NF- $\kappa \mathrm{B}$ activity. In response to pathogenic bacteria, the physical interaction between $\beta$-catenin and NF- $\kappa \mathrm{B}$ is compromised as a result of phosphorylation of $\beta$-catenin by GSK-3 $\beta$. P- $\beta$ catenin is subsequently degraded, liberating NF- $\kappa \mathrm{B}$ from its physical connection and repression by $\beta$-catenin. $\mathrm{I} \kappa \mathrm{B} \alpha$, the well-established negative regulator of NF- $\kappa \mathrm{B}$, is degraded in a similar manner as $\beta$-catenin after WT Salmonella infection. Following $\beta$-catenin and $\mathrm{I} \kappa \mathrm{B} \alpha$ degradation, free NF- $\kappa \mathrm{B}$ translocates to the nucleus, stimulating the production of proinflammatory cytokines such as IL-6 and IL-8. In contrast, colonization by the non-virulent Salmonella strain PhoP ${ }^{c}$ repressed GSK- $3 \beta$ kinase activity, thus stabilizing total $\beta$-catenin and the $\beta$-catenin/NF- $\kappa$ B complex. As a result, IL-6 and TNF- $\alpha$ secretion were suppressed compared to the mice with WT infection.

Our findings indicate that stabilization of $\beta$-catenin by inhibiting GSK-3 $\beta$ kinase activity has a significant effect in downregulating the NF- $\kappa \mathrm{B}$ pathway in IECs. A recent report on Toll-like receptor (TLR) agonist-stimulated monocytes demonstrated that GSK-3 $\beta$ is a pivotal factor in controlling whether a pro- or anti-inflammatory response is elicited after TLR activation. ${ }^{22}$ Inhibition of GSK-3 $\beta$ activity switched the response after LPS stimulation from proinflammatory, IL-12 releasing to anti-inflammatory, IL-10 producing. This antiinflammatory response to TLR stimulation in monocytes demonstrated that GSK $3 \beta$ could regulate the inflammatory responses. $^{22}$

A recent study in colon cancer and breast cancer cells has shown that inhibition of GSK-3 $\beta$ with $\mathrm{LiCl}$ can alter NF$\kappa \mathrm{B}$ activity, and that this cross-regulation occurs through $\beta$-catenin. ${ }^{23}$ Our published ${ }^{10}$ and unpublished data showed that $\mathrm{LiCl}$ inhibition of GSK- $3 \beta$ significantly decreased the amount of IL-8 secretion in response to WT Salmonella in small and large IECs. siRNA of GSK-3 $\beta$ was able to reduce $\mathrm{I} \kappa \mathrm{B} \alpha$ degradation and IL- 8 mRNA expression. Collectively, these data indicate that the regulation of NF- $\kappa \mathrm{B}$ activity by $\beta$-catenin stabilization is not restricted to epithelial cells, but is active in other cell lines as well.
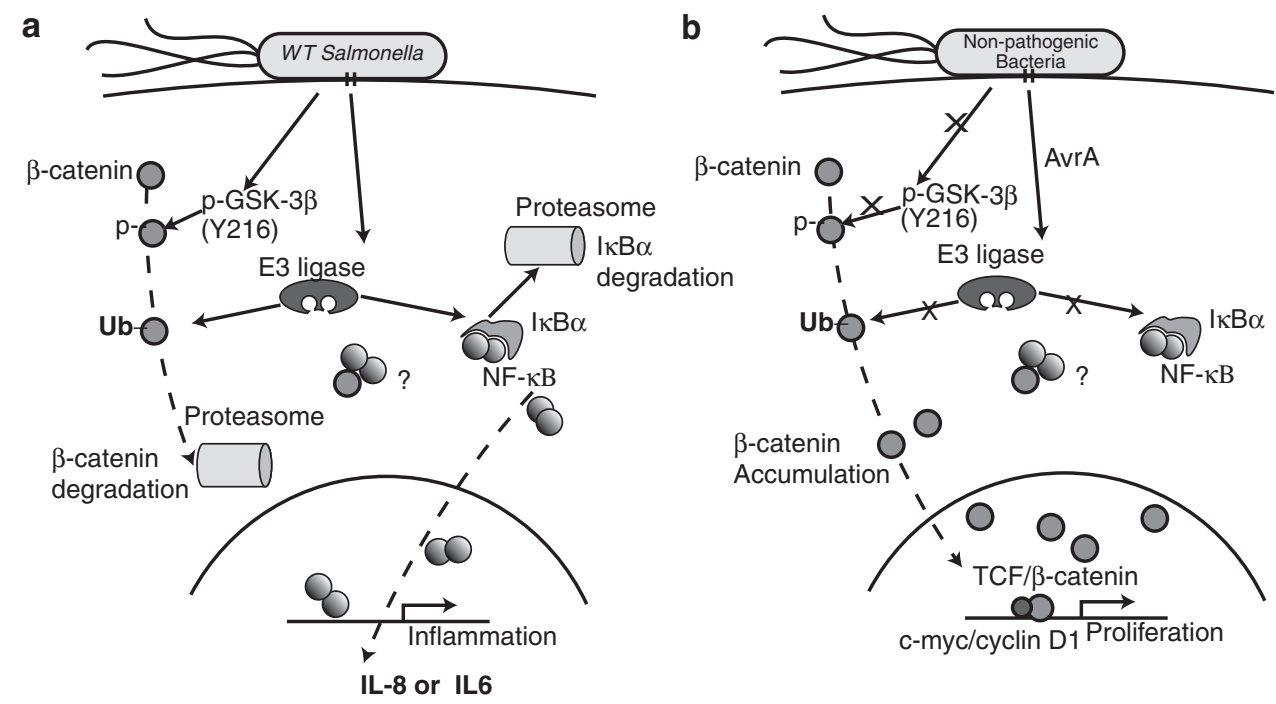

Figure 7 Proposed model for $\beta$-catenin inhibition of Salmonella-induced proinflammatory cascades. (a) WT Salmonella colonization of IECs stimulated phosphorylation of $\beta$-catenin and $\mathrm{I}_{\kappa} \mathrm{B} \alpha$ through GSK-3 $\beta$, and ubiquitination through E3 ligase. $\beta$-Catenin and $\mathrm{I}_{\kappa} \mathrm{B}$ are subsequently degraded in the proteasome, reducing their concentration within the cell. As a result, there is less NF- $\kappa \mathrm{B} / \beta$-catenin binding, less $\mid \kappa \mathrm{B}$, and NF- $\kappa \mathrm{B}$ freely translocates to the nucleus. Once in the nucleus, NF- $\kappa$ B activates transcription of IL-8 and other proinflammatory genes. (b) When avirulent Salmonella colonize epithelial cells, bacteria secrete AvrA, a bacterial effector protein. That may inhibit the phosphorylation and ubiquitination of $\beta$-catenin and $I \kappa \mathrm{B}$. I $k \mathrm{~B}$ is stabilized, and $\beta$ catenin is not degraded and accumulates in the nucleus. This allows for activation of the $\beta$-catenin signaling cascades and inhibition of NF- $\kappa \mathrm{B}$-dependent proinflammatory gene transcription. 
The involvement of GSK-3 $\beta$ phosphorylation and $\beta$-catenin in regulating the inflammatory cascade in response to bacterial challenge is not unique to Salmonella infection. The type three secretory system (TTSS)-dependent pathogen Yersinia stimulates GSK- $3 \beta$ phosphorylation during the early stages of macrophage infection. ${ }^{24}$ It is known that the TTSS Ipa effector proteins play prominent and diverse roles in Shigella-induced infection. ${ }^{25} \mathrm{Ipa}$ is able to bind with $\beta$-catenin. IpaC-associated $\beta$-catenin is tyrosine phosphorylated and destabilized, thus allowing for bacterial invasion. ${ }^{25} \mathrm{~A}$ study on Listeria showed that $\beta$-catenin and $\alpha$-catenin are recruited to the site of bacterial entry, which is necessary for the dynamic events that induce the cytoskeletal rearrangement and plasma membrane extensions in bacterial uptake. ${ }^{26}$ Our unpublished data also showed that WT enteropathogenic E. coli infection was able to reduce the total $\beta$-catenin expression in epithelial cells, whereas the phosphorylation of GSK-3 $\beta$ (Ser9) was increased. These results suggest that phosphorylation of GSK- $3 \beta$ and $\beta$-catenin stabilization provides important control points in the inflammatory cascade.

Our published data showed that AvrA, a bacterial effector in Salmonella, mediates the ubiquitination of $\beta$-catenin. ${ }^{5}$ Additionally, we showed that AvrA inhibited the NF- $\kappa \mathrm{B}$ pathways and consequently modulated cellular inflammation. ${ }^{27}$ We believe that the bacterial effector AvrA regulates the activation of NF- $\kappa \mathrm{B}$ through $\beta$-catenin stabilization. Future characterization of the precise function of AvrA in vivo will give new clues concerning microbial-host interaction in inflammation.

We propose that the Salmonella-induced proinflammatory cascade involves both the $\beta$-catenin and NF- $\kappa \mathrm{B}$ pathways (Figure 7). WT Salmonella triggers the proinflammatory response, including $\mathrm{I} \kappa \mathrm{B} \alpha$ degradation, NF- $\kappa \mathrm{B}$ activation, and IL-8 secretion in epithelial cells. However, we have shown that the same stimulation by WT Salmonella also causes $\beta$-catenin degradation by increasing the activity of phosphorylated GSK-3 $\beta$ (Figure 7a). We propose that phosphorylation of GSK-3 $\beta$ provides a pivotal control site for the stability of $\beta$-catenin, which not only controls the cell's fate, apoptosis $v s$ proliferation, but also modulates the magnitude of inflammation, through the activity of NF- $\kappa$ B. Phosphorylation of $\beta$-catenin by GSK- $3 \beta$ destabilizes $\beta$-catenin and thus prevents its interference with NF- $\kappa \mathrm{B}$ signaling. In contrast, non-pathogenic bacteria stabilize $\beta$-catenin by inhibiting $\beta$-catenin phosphorylation through GSK-3 $\beta$ and ubiquitination of $\beta$-catenin. ${ }^{5}$ Stabilization of $\beta$-catenin represses NF- $\kappa$ B-dependent inflammatory pathways and inhibits IL-8 secretion during bacterial colonization (Figure $7 \mathrm{~b}$ ).

In conclusion, we examined the role of GSK- $3 \beta$ in modulating the $\beta$-catenin response to WT Salmonella. Our data showed that bacteria modulate $\beta$-catenin stabilization by stimulating $\beta$-catenin phosphorylation through the kinase activity of GSK-3 $\beta$. Pathogenic bacteria increased $\beta$-catenin phosphorylation by increasing GSK-3 $\beta$ activity, thus redu- cing the total $\beta$-catenin expression and $\beta$-catenin/NF- $\kappa \mathrm{B}$ binding. On the other hand, non-pathogenic bacteria are capable of stabilizing $\beta$-catenin and activating the $\beta$-catenin pathway by inhibiting GSK-3 $\beta$ activity. Consequently, $\beta$ catenin levels are maintained and activation of the NF- $\kappa \mathrm{B}$ pathway is prevented. This idea is in agreement with our results showing that stabilization of $\beta$-catenin represses NF- $\kappa$ B pathway activation and inhibits IL- 8 or IL- 6 secretion during bacterial colonization both in vitro ${ }^{22}$ and in vivo. Thus, our findings suggest that activated $\beta$-catenin may play an important role in modulating bacteria-induced inflammatory responses.

\section{ACKNOWLEDGEMENT}

We thank Dr James L Madara for conversational input during the course of this work, Vesta Valuckaite for her technical assistance, Dr Yang-Xin Fu for providing MEF p65-/- and MEF p65 + / +, and Drs Kenneth Kinzler and Bert Vogelstein of the Johns Hopkins Medical Institution, Baltimore, MD, for providing the human colorectal cancer line HCT116 (CTNNB1 ${ }^{\mathrm{WT} / \Delta 45}$ ) and its somatic CTNNB1 knockout lines HCT116 $6^{-/ \Delta 45}$ and HCT116 $16^{\mathrm{WT} /-}$. This work was supported by NIH DK-075386 and a Pilot \& Feasibility Award from the Digestive Disease Research Core Center, The University of Chicago DK42086 to JS, DK-47722 to MC, and DK-47662 and DK-35932 to JLM.

1. Finlay BB, McFadden G. Anti-immunology: evasion of the host immune system by bacterial and viral pathogens. Cell 2006;124:767-782.

2. Haller D, Russo MP, Sartor RB, et al. IKK beta and phosphatidylinositol 3-kinase/Akt participate in non-pathogenic Gram-negative enteric bacteria-induced RelA phosphorylation and NF-kappa B activation in both primary and intestinal epithelial cell lines. J Biol Chem 2002;277:38168-38178.

3. Li ZW, Rickert RC, Karin M. Genetic dissection of antigen receptor induced-NF-kappaB activation. Mol Immunol 2004;41:701-714.

4. Neish AS, Gewirtz AT, Zeng $H$, et al. Prokaryotic regulation of epithelial responses by inhibition of IkappaB-alpha ubiquitination. Science 2000;289:1560-1563.

5. Sun J, Hobert ME, Rao AS, et al. Bacterial activation of beta-catenin signaling in human epithelia. Am J Physiol Gastrointest Liver Physiol 2004;287:G220-G227.

6. Fuchs SY, Chen A, Xiong Y, et al. HOS, a human homolog of Slimb, forms an SCF complex with Skp1 and Cullin1 and targets the phosphorylation-dependent degradation of IkappaB and beta-catenin. Oncogene 1999;18:2039-2046.

7. Winston JT, Strack P, Beer-Romero P, et al. The SCFbeta-TRCP-ubiquitin ligase complex associates specifically with phosphorylated destruction motifs in IkappaBalpha and beta-catenin and stimulates IkappaBalpha ubiquitination in vitro. Genes Dev 1999;13:270-283.

8. Barthel M, Hapfelmeier S, Quintanilla-Martâinez L, et al. Pretreatment of mice with streptomycin provides a Salmonella enterica serovar Typhimurium colitis model that allows analysis of both pathogen and host. Infect Immun 2003;71:2839-2858.

9. Grèone HJ, Weber K, Helmchen U, et al. Villin-a marker of brush border differentiation and cellular origin in human renal cell carcinoma. Am J Pathol 1986;124:294-302.

10. Sun J, Hobert ME, Duan Y, et al. Crosstalk between NF-kappaB and beta-catenin pathways in bacterial-colonized intestinal epithelial cells. Am J Physiol Gastrointest Liver Physiol 2005;289:G129-G137.

11. Miller SI, Mekalanos JJ. Constitutive expression of the phoP regulon attenuates Salmonella virulence and survival within macrophages. J Bacteriol 1990;172:2485-2490.

12. Behrens J, Jerchow BA, Wèurtele $M$, et al. Functional interaction of an axin homolog, conductin, with beta-catenin, APC, and GSK3beta. Science 1998;280:596-599.

13. Hamada F, Tomoyasu Y, Takatsu Y, et al. Negative regulation of Wingless signaling by D-axin, a Drosophila homolog of axin. Science 1999;283:1739-1742. 
14. Itoh K, Krupnik VE, Sokol SY. Axis determination in Xenopus involves biochemical interactions of axin, glycogen synthase kinase 3 and beta-catenin. Curr Biol 1998;8:591-594.

15. He TC, Sparks AB, Rago C, et al. Identification of c-MYC as a target of the APC pathway. Science 1998;281:1509-1512.

16. Doble BW, Woodgett JR. GSK-3: tricks of the trade for a multi-tasking kinase. J Cell Sci 2003;116:1175-1186.

17. Fuchs SY, Spiegelman VS, Kumar KG. The many faces of beta-TrCP E3 ubiquitin ligases: reflections in the magic mirror of cancer. Oncogene 2004;23:2028-2036.

18. Bhat RV, Shanley J, Correll MP, et al. Regulation and localization of tyrosine216 phosphorylation of glycogen synthase kinase-3beta in cellular and animal models of neuronal degeneration. Proc Natl Acad Sci USA 2000;97:11074-11079.

19. Cross DA, Alessi DR, Cohen $P$, et al. Inhibition of glycogen synthase kinase- 3 by insulin mediated by protein kinase B. Nature 1995;378:785-789.

20. Chan TA, Wang Z, Dang LH, et al. Targeted inactivation of CTNNB1 reveals unexpected effects of beta-catenin mutation. Proc Natl Acad Sci USA 2002;99:8265-8270.
21. Morin PJ, Sparks AB, Korinek V, et al. Activation of beta-catenin-Tcf signaling in colon cancer by mutations in beta-catenin or APC. Science 1997;275:1787-1790.

22. Martin M, Rehani K, Jope RS, et al. Toll-like receptor-mediated cytokine production is differentially regulated by glycogen synthase kinase 3 . Nat Immunol 2005;6:777-784.

23. Deng J, Xia W, Miller SA, et al. Crossregulation of NF-kappaB by the APC/GSK-3beta/beta-catenin pathway. Mol Carcinog 2004;39:139-146.

24. Sauvonnet N, Lambermont I, van der Bruggen $\mathrm{P}$, et al. YopH prevents monocyte chemoattractant protein 1 expression in macrophages and T-cell proliferation through inactivation of the phosphatidylinositol 3-kinase pathway. Mol Microbiol 2002;45:805-815.

25. Shaikh N, Terajima J, Watanabe H. IpaC of Shigella binds to the C-terminal domain of beta-catenin. Microb Pathog 2003;35:107-117.

26. Lecuit M, Hurme R, Pizarro-Cerda J, et al. A role for alpha-and beta-catenins in bacterial uptake. Proc Natl Acad Sci USA 2000;97: 10008-10013.

27. Collier-Hyams LS, Zeng H, Sun J, et al. Cutting edge: Salmonella AvrA effector inhibits the key proinflammatory, anti-apoptotic NF-kappa B pathway. J Immunol 2002;169:2846-2850. 